\title{
SCABIOSA COLUMBARIA: A REVIEW OF ITS MEDICINAL USES, PHYTOCHEMISTRY, AND BIOLOGICAL ACTIVITIES
}

\author{
ALFRED MAROYI* \\ Department of Botany, Medicinal Plants and Economic Development Research Centre, University of Fort Hare, Private Bag X1314, \\ Alice 5700, South Africa. Email: amaroyi@ufh.ac.za
}

Received: 02 May 2019, Revised and Accepted: 14 June 2019

\begin{abstract}
Scabiosa columbaria is a perennial herb widely used as herbal medicine throughout its distributional range in tropical Africa, Asia, and Europe. This study is aimed at providing a critical review of the biological activities, phytochemistry, and medicinal uses of $S$. columbaria. Documented information on biological activities, medicinal uses, and phytochemistry of $S$. columbaria was collected from several online sources which included BMC, Scopus, SciFinder, Google Scholar, ScienceDirect, Elsevier, PubMed, and Web of Science. Additional information on the biological activities, phytochemistry, and medicinal uses of $S$. columbaria was gathered from pre-electronic sources such as book chapters, books, journal articles, theses, and scientific publications sourced from the university library. This study showed that the aerial parts, leaves, roots, stems, and the whole plant parts of $S$. columbaria are used as colic, love charm and for magical purposes, and as herbal medicine for eye problems, heartburn, respiratory problems, wounds, female infertility, venereal diseases, skin infections, and menstrual problems. Phytochemical compounds identified from the aerial parts and roots of $S$. columbaria are glycoside scabiosin, loganin, sweroside, palmitic acid, phthalic acid, diisooctyl phthalate, bis-(ethylhexyl) phthalate, and dibutyl phthalate. Pharmacological research revealed that $S$. columbaria extracts and compounds have antibacterial, antifungal, and antiprotozoan activities. Future research should focus on evaluating the phytochemical, pharmacological, and toxicological properties of $S$. columbaria crude extracts as well as compounds isolated from the species.
\end{abstract}

Keywords: Caprifoliaceae, Dipsacaceae, Ethnopharmacology, Herbal medicine, Indigenous pharmacopeia, Scabiosa columbaria.

(C) 2019 The Authors. Published by Innovare Academic Sciences Pvt Ltd. This is an open access article under the CC BY license (http://creativecommons. org/licenses/by/4. 0/) DOI: http://dx.doi.org/10.22159/ajpcr.2019.v12i8.34229

\section{INTRODUCTION}

Scabiosa columbaria L. is a member of the Dipsacaceae or teasel family. Although the species is often included in the family Caprifoliaceae in some classification systems [1-3], the phylogenetic analyses of both the chloroplast and nuclear genomes as well as their combination show that Dipsacaceae is a monophyletic group [4-11]. The Dipsacaceae family contains about 300 species of annual and perennial herbs or shrubs that have been recorded mainly in the Mediterranean Basin, with about 20\% distributed in Asia, Eastern and Southern Africa [7,11,12]. The genus Scabiosa L. has been recorded in Europe, primarily in the Mediterranean Basin (five species and two species complexes that include about 14 taxa), Asia (12 species), and Eastern and Southern Africa (eight species) [13]. The species of Scabiosa are mainly annuals; others are perennials, with some of the species characterized by woody rootstocks [14]. Several species of the genus Scabiosa are widely used in the food, cosmetic, and pharmaceutical industries [15]. The biological activities of Scabiosa species include antibacterial, analgesic, antidiabetic, hepatoprotective, anti-inflammatory, antifungal, antioxidant, antiviral, and anti-parasitic and these pharmacological activities are closely related to its high content of phenolic compounds, and these activities corroborate the beneficial properties of these medicinal plants [16].

Research by Van Wyk [17] showed that the leaves and roots of $S$. columbaria $\mathrm{L}$. have commercial potential as colic and herbal medicine for heartburn in South Africa. Moreover, the roots and whole plants of $S$. columbaria are sold as herbal medicines in informal herbal medicine markets in $66.7 \%$ of the provinces in South Africa, that is, in the Eastern Cape [18], Gauteng [19-22], KwaZulu-Natal [23], Limpopo [24], Mpumalanga [22], and Northern Cape [25] Provinces. Williams [19] categorized $S$. columbaria as a fast-selling and popular herbal medicine, with its roots purchased at least once a day in the Witwatersrand herbal medicine informal market in the Gauteng Province in South
Africa. Research by Williams et al. [26] showed that 58\% of informal herbal medicine shops in the Gauteng Province were selling the whole plants of $S$. columbaria in 1995 at prices ranging from R77.3 to $\mathrm{R} 98.6 / \mathrm{kg}$ (US\$21.3-US\$27.2). S. columbaria has been incorporated into the traditional material medica in South Africa and is included in the book "medicinal plants of South Africa," a photographic guide to the most commonly used plant medicines in the country, with a potential contribution to primary health care of local communities in South Africa. Therefore, this is the rationale behind the current study, aimed at providing a critical review of the ethnomedicinal uses, phytochemistry, and biological activities of $S$. columbaria as well as exploring the potential of the species as herbal medicine.

\section{BOTANICAL DESCRIPTION OF S. COLUMBARIA}

S. columbaria is native to Southern, East and North Africa, temperate Asia and Europe [27-46]. In Europe, S. columbaria has been recorded exclusively in semi-dry or dry grasslands, a vegetation type which has been drastically reduced in the Swiss lowlands, and to a lesser extent in the Pre-alps and the Swiss Jura mountains, due to land-use changes and transformation processes in the last decades [47]. In Italy, $S$. columbaria has been recorded in grasslands, arid pastures, nutrient poor habitats, grazed, and mown calcareous grasslands [48]. $S$. columbaria is considered endangered in the Netherlands $[49,50]$, the Pre-alps and the Swiss Jura mountains in Northern Switzerland [51]. In Africa, S. columbaria has been recorded in open woodland, grassland, Bushveld, sandy flats, rocky slopes, mountain slopes, and valleys at an altitude ranging from $5 \mathrm{~m}$ to $3475 \mathrm{~m}$ above sea level [28,33,34]. The genus name "Scabiosa" is derived from the word scabies meaning "to scratch" because, in medieval times, the species was used as an herbal medicine for scabies, skin sores, and other skin infections [52]. The specific epithet, "columbaria" is a Latinized word meaning "dove-like or dove-colored" in reference to some flower forms of the species $[46,52]$. Two infra species of $S$. columbaria are recognized, 
namely $S$. columbaria subsp. banatica (Waldst. and Kit.) Diklic, and S. columbaria subsp. Caespitosa Jamzad. The common English names of S. columbaria include butterfly blue and wild scabious [53].

S. columbaria is a perennial evergreen herb up to $1 \mathrm{~m}$ in height with annual branches developing from persistent fleshy roots [52,53]. The leaves are oblanceolate in shape, thin-textured, slightly hairy, and variable in shape with characteristically lobed margins forming a rosette on the ground. The basal leaves have serrated margins, while those higher on the stems have deeply lobed margins. The long, slender, erect, and seldom branched stems have a terminal head of small flowers which are surrounded by bristly bracts. The flowers are compact, pink, and sometimes white or lilac in color [52].

\section{MEDICINAL USES OF S. COLUMBARIA}

The aerial parts, leaves, roots, stems, and the whole plant parts of $S$. columbaria are used as herbal medicines against 20 human diseases in Southern Africa and Europe (Table 1). S. columbaria is mainly used as colic, love charm, and for magical purposes, and as an herbal medicine for eye problems, heartburn, respiratory problems, wounds, female infertility, venereal diseases, skin infections, and menstrual problems (Fig. 1). In Lesotho, the roots of $S$. columbaria are mixed with those of
Dicoma anomala Sond. or leaves of Asclepias humilis (E. Mey.) Schltr. and rhizome of Gunnera perpensa L. or those of Searsia divaricata (Eckl. \& Zeyh.) Moffett and Cussonia paniculata Thunb. as herbal medicine for menstrual problems [54-59]. The roots of $S$. columbaria are mixed with those of $S$. divaricata and $C$. paniculata and used as colic [54]. The roots of $S$. columbaria are mixed with those of Aster bakerianus Burtt Davy ex C.A.Sm. as herbal medicine for skin rash [60,61] and roots of $S$. columbaria are mixed with those of D. anomala, Helichrysum caespititium (DC.) Sond. ex Harv. and Zantedeschia albomaculata (Hook.) Baill. as herbal medicine for venereal diseases [59,62,63]. Apart from its usage as herbal medicine, $S$. columbaria is also used as a leafy vegetable in Italy [64].

\section{PHYTOCHEMISTRY OF S. COLUMBARIA}

The compound glycoside scabiosin has been isolated from the roots of S. columbaria [66] while Horn et al. [73] identified two iridoid glycosides, namely, loganin and sweroside from the roots of $S$. columbaria. Vinnitska [93] isolated palmitic acid, phthalic acid, diisooctyl phtalate, bis-(ethylhexyl) phthalate, and dibutyl phthalate from the aerial parts of $S$. columbaria. Horn et al. [73] evaluated the antibacterial activities of the compounds loganin and sweroside isolated from the roots of S. columbaria against Bacillus cereus, Bacillus pumilus, Bacillus subtilis,

Table 1: Medicinal uses of Scabiosa columbaria

\begin{tabular}{|c|c|c|c|}
\hline Medicinal use & Parts of the plant used & Country & References \\
\hline Abdominal pains & Roots and stems & Lesotho & {$[65]$} \\
\hline Augmentation of labor & Roots & Lesotho & {$[54,60]$} \\
\hline $\begin{array}{l}\text { Broncho-sedative, fluidizing, } \\
\text { purifying, and sialagogue }\end{array}$ & Roots & Italy & [48] \\
\hline Chilblains & Roots & Italy & {$[48]$} \\
\hline Colic & Leaves and roots & South Africa and Swaziland & {$[52,53,66-69]$} \\
\hline Colic & $\begin{array}{l}\text { Roots mixed with Searsia divaricata (Eckl. } \\
\text { and Zeyh.) Moffett and Cussonia paniculata } \\
\text { Thunb }\end{array}$ & Lesotho & [54] \\
\hline Constipation & Whole plant & Turkey & {$[70]$} \\
\hline Diuretic & Whole plant & Turkey & [70] \\
\hline Eye problems & Leaves and roots & South Africa and Swaziland & {$[67,67,71]$} \\
\hline Female infertility & Roots & Lesotho and South Africa & {$[52,57,60,66,67,72-75]$} \\
\hline Heartburn & Leaves and roots & South Africa and Swaziland & {$[52,53,68,69]$} \\
\hline High blood pressure & Leaves and roots & Lesotho & {$[76,77]$} \\
\hline $\begin{array}{l}\text { Love charm and magical } \\
\text { purposes }\end{array}$ & Roots & South Africa and Swaziland & {$[68,71,78,79]$} \\
\hline Menstrual problems & Leaves, roots, and stems & $\begin{array}{l}\text { Lesotho, South Africa, and } \\
\text { Swaziland }\end{array}$ & {$[52,65,67,68,72,74,76,77,80]$} \\
\hline Menstrual problems & Roots mixed with Dicoma anomala Sond. & Lesotho & {$[54,55,59]$} \\
\hline Menstrual problems & $\begin{array}{l}\text { Roots mixed with leaves of Asclepias } \\
\text { humilis (E. Mey.) Schltr. and rhizome of } \\
\text { Gunnera perpensa L. }\end{array}$ & Lesotho & {$[56-58]$} \\
\hline Menstrual problems & $\begin{array}{l}\text { Roots mixed with } S \text {. divaricata and } \\
\text { C. paniculata }\end{array}$ & Lesotho & {$[54]$} \\
\hline $\begin{array}{l}\text { Pregnancy complications and } \\
\text { cleanses womb }\end{array}$ & Leaves and roots & Lesotho & {$[57,60,76,77]$} \\
\hline $\begin{array}{l}\text { Reduces mother-child HIV } \\
\text { transmission }\end{array}$ & Leaves and roots & Lesotho & {$[76,77,81]$} \\
\hline $\begin{array}{l}\text { Respiratory problems, } \\
\text { diphtheria, and flu }\end{array}$ & Aerial parts, leaves, and roots & $\begin{array}{l}\text { Iberian Peninsula and } \\
\text { Lesotho }\end{array}$ & {$[76,77,82-84]$} \\
\hline $\begin{array}{l}\text { Skin infections (acariosis, } \\
\text { dermatitis, eczema, follicular } \\
\text { acne, fungus-borne skin } \\
\text { disease, measles, and rash) }\end{array}$ & Leaves, roots, and stems & $\begin{array}{l}\text { Iberian Peninsula, Italy and } \\
\text { South Africa }\end{array}$ & {$[48,79,85]$} \\
\hline Skin rash & $\begin{array}{l}\text { Roots mixed with Aster bakerianus Burtt } \\
\text { Davy ex C.A.Sm. }\end{array}$ & Lesotho & {$[60,61]$} \\
\hline Uterine disorders & Leaves and roots & Lesotho & {$[76,86]$} \\
\hline Venereal diseases & $\begin{array}{l}\text { Roots mixed D. anomala, Helichrysum } \\
\text { caespititium (DC.) Sond. ex Harv. and } \\
\text { Zantedeschia albomaculata (Hook.) Baill. }\end{array}$ & Lesotho & {$[59,62,63]$} \\
\hline Venereal sores & Roots & Lesotho and South Africa & {$[53,54,60,66,67,72,77,81,87,88]$} \\
\hline Wounds & Leaves, roots, and whole plant & South Africa and Turkey & {$[53,70,89-92]$} \\
\hline
\end{tabular}




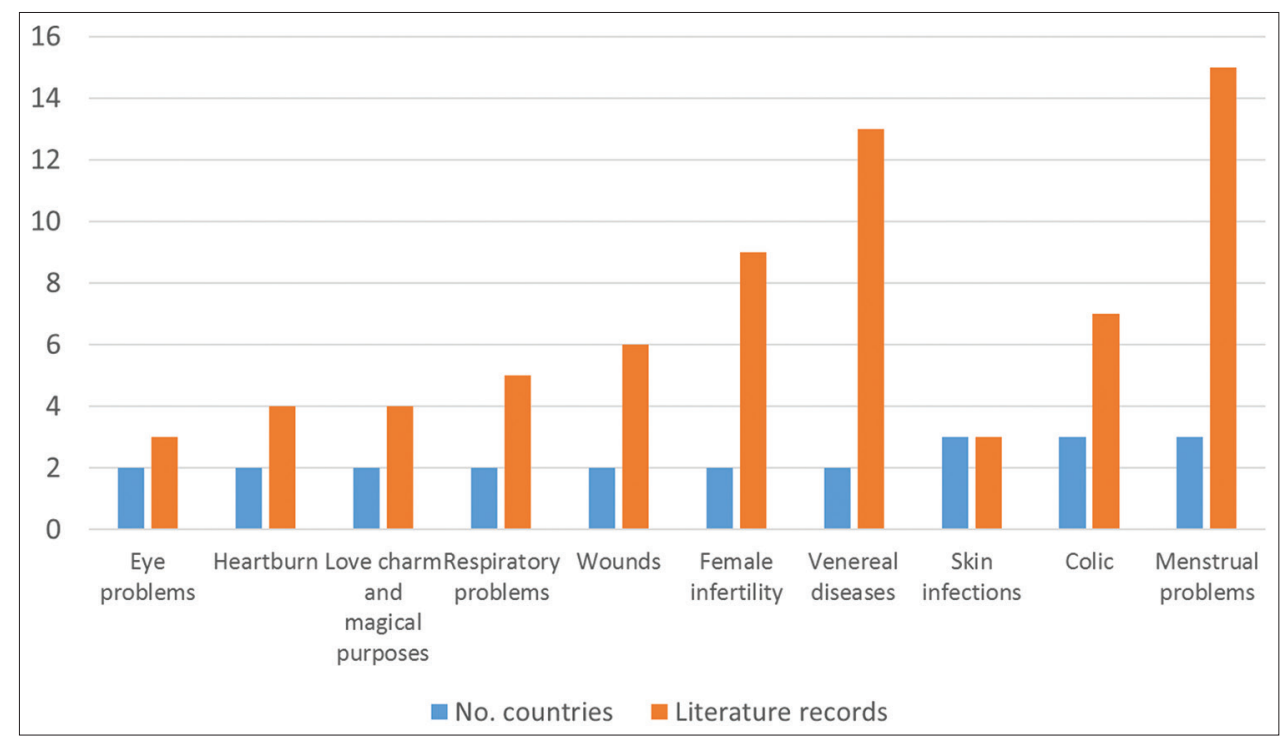

Fig. 1: Medicinal applications of Scabiosa columbaria derived from literature records

Micrococcus kristinae, Staphylococcus aureus, Escherichia coli, Klebsiella pneumoniae, Pseudomonas aeruginosa, Enterobacter cloacae, and Serratia marcescens at concentrations of $0.001 \mathrm{mg} / \mathrm{ml}-1.0 \mathrm{mg} / \mathrm{ml}$. The compound sweroside showed moderate activities at a concentration of $1.0 \mathrm{mg} / \mathrm{ml}$ against all tested pathogens with the exception of S. marcescens [73].

\section{BIOLOGICAL ACTIVITIES OF S. COLUMBARIA EXTRACTS}

From literature, only antibacterial [77,88], antifungal [88], and antiprotozoan [88] activities were identified.

\section{Antibacterial activities}

Van Vuuren and Naidoo [88] evaluated antibacterial activities of aqueous and a mixture of methanol and dichloromethane (1:1) leaf and root extracts of $S$. columbaria against bacterial pathogens associated with urogenital or sexually transmitted infections which included Gardnerella vaginalis, Neisseria gonorrhoeae, Oligella ureolytica, and Ureaplasma urealyticum using the microdilution technique with ciprofloxacin $(0.01 \mathrm{mg} / \mathrm{ml})$ as a positive control. The extracts exhibited activities with minimal inhibitory concentration (MIC) values ranging from $2.0 \mathrm{mg} / \mathrm{ml}$ to $>16.0 \mathrm{mg} / \mathrm{ml}$ which were higher than $0.1 \mathrm{mg} / \mathrm{ml}$ exhibited by the control [88]. Seleteng-Kose [77] evaluated the antibacterial activities of aqueous and organic root extracts of S. columbaria against Citrobacter freundii, Enterobacter homaendis, K. pneumoniae, Moraxella catarrhalis, Mycobacterium fortuitum, Mycobacterium smegmatis, and S. aureus using microdilution technique using ciprofloxacin $(0.01 \mathrm{mg} / \mathrm{ml})$ as a positive control. The extracts showed activities against all tested microorganisms with the exception of Mycobacterium fortuitum and Mycobacterium smegmatis, exhibiting MIC values ranging from $1.3 \mathrm{mg} / \mathrm{ml}$ to $>8.0 \mathrm{mg} / \mathrm{ml}$ [77].

\section{Antifungal activities}

Van Vuuren and Naidoo [88] evaluated antifungal activities of aqueous and a mixture of methanol and dichloromethane (1:1) leaf and root extracts of $S$. columbaria against fungal pathogen associated with urogenital or sexually transmitted infections, Candida albicans using the microdilution technique with amphotericin B $(0.1 \mathrm{mg} / \mathrm{ml})$ as a positive control. The extracts exhibited activities with MIC values ranging from $2.0 \mathrm{mg} / \mathrm{ml}$ to $8.0 \mathrm{mg} / \mathrm{ml}$, which were comparable to MIC value of $2.5 \mathrm{mg} / \mathrm{ml}$ exhibited by the control [88].

\section{Antiprotozoan activities}

Van Vuuren and Naidoo [88] evaluated antiprotozoal an activities of aqueous and a mixture of methanol and dichloromethane (1:1) leaf and root extracts of $S$. columbaria against protozoan pathogen associated with urogenital or sexually transmitted infections, Trichomonas vaginalis using the microdilution technique with ciprofloxacin $(0.01 \mathrm{mg} / \mathrm{ml})$ as a positive control. The extracts exhibited activities with MIC values ranging from $3.0 \mathrm{mg} / \mathrm{ml}$ to $>16.0 \mathrm{mg} / \mathrm{ml}$ which were higher than $0.1 \mathrm{mg} / \mathrm{ml}$ exhibited by the control [88].

\section{CONCLUSION}

The diverse medicinal uses of $S$. columbaria documented throughout the distributional range of the species and the scientific evidence of its phytochemistry and biological activities indicates its potential as herbal medicine. The preliminary pharmacological activities carried out so far are directly or indirectly involved in the protection against the growth of undesirable microbes. There is a need for further research on the phytochemistry, pharmacological, and toxicological activities of the crude extracts and compounds isolated from the species. Future research should also focus on the clinical significance of the pharmacological properties, cytotoxicity, and toxicity using in vivo models. The biological potency of such phytochemicals and crude extracts need to be evaluated aimed at exploring the potential of the species as herbal medicine.

\section{ACKNOWLEDGMENTS}

I would like to express my gratitude to the Govan Mbeki Research and Development Centre (GMRDC), University of Fort Hare for financial support to conduct this study.

\section{AUTHORS' CONTRIBUTIONS}

The author declares that this work was done by the author named in this article.

\section{CONFLICTS OF INTEREST}

The author declares that they have no conflicts of interest.

\section{REFERENCES}

1. Mostafa EN, Sedigheh NS. Palynological study of some Iranian species of Scabiosa L. (Caprifoliaceae). Bangladesh J Plant Taxonomy 2016;23:215-22

2. Erarslan ZB, Yesil Y. The anatomical properties of Scabiosa atropurpurea L. (Caprifoliaceae). Istanbul J Pharm 2018;48:1-5.

3. Guacchio ED, Cennamo P, Caputo P. The Linnaean names in Scabiosa (Caprifoliaceae: Dipsacoideae). Taxon 2018;67:422-36.

4. Zhang WH, Chen ZD, Ki JH, Chen YC, Anndtang HB. Phylogeny of the Dipsacales. S.L. based on chloroplast $t \mathrm{trnL}-F$ and $\mathrm{ndhF}$ sequences. 
Mol Phylogenet Evol 2003;26:176-89.

5. Winkworth RC, Bell CD, Donoghue MJ. Mitochondrial sequence data and Dipsacales phylogeny: Mixed models, partitioned Bayesian analyses, and model selection. Mol Phylogenet Evol 2008;46:830-43.

6. Avino M, Tortoriello G, Caputo P.Aphylogenetic analysis of Dipsacaceae based on four DNA regions. Plant Syst Evol 2009;279:69-86.

7. Carlson SE, Mayer V, Donoghue MJ. Phylogenetic relationships, taxonomy, and morphological evolution in Dipsacaceae (Dipsacales) inferred by DNA sequence data. Taxon 2009;58:1075-91.

8. Rossello JA, Cosin R, Bacchetta G, Brullo S, Mayol M. Nuclear and chloroplast DNA variation in Cephalariasquamiflora (Dipsacaceae), a disjunct Mediterranean species. Taxon 2009;58:1242-53.

9. Carlson SE, Howarth DG, Donoghue MJ. Diversification of CYCLOIDEA-like genes in Dipsacaceae (Dipsacales): Implications for the evolution of capitulum inflorescences. BMC Evol Biol 2011;11:325

10. Mayer V, Ehrendorfer F. The phylogenetic position of Pterocephalidium and the new African genus Pterothamnus within an improved classification of Dipsacaceae. Taxon 2013;62:112-16.

11. Mayer V. Dipsacaceae (inclusive Triplostegia). In: Kadereit JW, Bittrich V, editors. The Families and Genera of Vascular Plants: Flowering Plants: Eudicots, Aquifoliales, Boraginales, Bruniales, Dipsacales, Escalloniales, Garryales, Paracryphiales, Solanales (except Convolvulaceae), Icacinaceae, Metteniusaceae, Vahliaceae. Cham: Springer; 2016. p. 145-64.

12. Manning JC, Goldblatt P, Johns A. A taxonomic review of Cephalaria (Dipsacaceae) in the cape floristic region. S Afr J Bot 2014;94:195-203.

13. Carlson SE, Linder PH, Donoghue MJ. The historical biogeography of Scabiosa (Dipsacaceae): Implications for old world plant disjunctions. J Biogeogr 2012;39:1086-100.

14. Suyama C, Ueda K. Taxonomic revision of Scabiosa jezoensis (Dipsacaceae) in Japan. Kew Bull 2007;62:95-105.

15. Al-Qudah MA, Otoom NK, Al-Jaber HI, Tashtoush HI, Mayyas AS, Trawenh IN, et al. Chemical composition of essential oil of Jordanian Scabiosa prolifera at different flowering stages. Jordan J Chem 2016;11:99-107.

16. Hlila MB, Majouli K, Mosbah H, Jannet HB, Aouni M, Selmi B. Phytochemical and pharmacological properties of Scabiosa L. Genus. In: Berhardt LV, editor. Advances in Medicine and Biology. New York: Nova Science Publishers; 2017. p. 105-38.

17. Van Wyk BE. The potential of South African plants in the development of new food and beverage products. S Afr J Bot 2011;77:857-68.

18. Dold AP, Cocks ML. The trade in medicinal plants in the Eastern Cape province, South Africa. S Afr J Sci 2002;98:589-97.

19. Williams VL. The Witwatersrand muti trade. Veld Flora 1996;82:12-4

20. Williams VL, Balkwill K, Witkowski ET. A lexicon of plants traded in the Witwatersrand umuthi shops. Bothalia 2001:31:71-98.

21. Williams VL, Balkwill K, Witkowski ET. Size-class prevalence of bulbous and perennial herbs sold in the Johannesburg medicinal plant markets between 1995 and 2001. S Afr J Bot 2007;73:144-55.

22. Botha J, Weiersbye IM. Ethnobotanic and forage uses of plants on mine properties in the Witwatersrand basin gold fields, South Africa. In: Fourie A, Tibbett M, Wiertz J, editors. Mine closure. Perth: Australian Centre for Geomechanics; 2010. p. 325-42.

23. Cunningham AB. African Medicinal Plants: Setting Priorities at the Interface between Conservation and Primary Health Care. Paris: People and Plants Working Paper 1, UNESCO; 1993

24. Moeng TE. An Investigation into the Trade of Medicinal Plants by Muthi Shops and Street Vendors in the Limpopo Province, South Africa. MSc Dissertation. Sovenga: University of Limpopo; 2010.

25. Monakisi CM. Knowledge and use of Traditional Medicinal Plants by the Setswana-Speaking Community of Kimberley, Northern Cape of South Africa. MSc Dissertation. Cape Town: Stellenbosch University; 2007.

26. Williams VL, Witkowski ET, Balkwill K. Volume and financial value of species traded in the medicinal plant markets of Gauteng, South Africa. Int J Sustain Dev World Ecol 2007;14:584-603.

27. Tutin TG, Heywood VH, Burges NA, Moore DM, Valentine DH, Walters SM, et al. Flora Europaea 4. Cambridge: Cambridge University Press; 1976.

28. Cannon MJ, Cannon JF. Dipsacaceae. In: Launert E, editor. Flora Zambesiacavol. Vol. 7. Part 1. London: Flora Zambesiaca Managing Committee; 1983. p. 77-85.

29. Fabian A, Germishuizen G. Wild Flowers of Northern South Africa. Vlaeburg: Fernwood Press; 1997.

30. Wood JR. A handbook of the Yemen Flora. London, Kew: Royal Botanic Gardens; 1997.
31. Collenette S. Wildflowers of Saudi Arabia. Riyadh: National Commission for Wildlife Conservation and Development (NCWCD); 1999.

32. Waldmann P, Andersson S. Multilocus and multitrait differentiation of populations of the locally rare plant Scabiosa canescens and the more common S. columbaria. Hereditas 1999;130:341-3.

33. Germishuizen G, Meyer NL. Plants of Southern Africa: An Annotated Checklist. Pretoria: Strelitzia, 14, National Botanical Institute; 2003.

34. Hedberg I, Edwards S, Nemomissa S. Flora of Ethiopia and Eritrea. Vol. 4. Addis Ababa: The National Herbarium; 2003.

35. Picó FX, Ouborg NJ, Van Groenendael JM. Evaluation of the extent of among-family variation in inbreeding depression in the perennial herb Scabiosa columbaria (Dipsacaceae). Am J Bot 2004;91:1183-9.

36. Burrows JE, Willis CK. Plants of the Nyika Plateau: An Account of the Vegetation of the Nyika National Parks of Malawi and Zambia. Pretoria: Southern African Botanical Diversity Network Report No. 31, SABONET; 2005

37. Bandeira S, Bolnick D, Barbosa F. Wild Flowers of Southern Mozambique. Maputo: Universidade Eduardo Mondlane; 2007.

38. Figueiredo E, Smith GF. Plants of Angola. Pretoria: Strelitzia 22, National Botanical Institute; 2008

39. Von Hagen KB, Seidler G, Welk E. New evidence for a postglacial homoploid hybrid origin of the widespread Central European Scabiosa columbaria L. s. str. (Dipsacaceae). Plant Syst Evol 2008;274:179-91.

40. Reisch C, Poschlod P. Land use affects flowering time: Seasonal and genetic differentiation in the grassland plant Scabiosa columbaria. Evol Ecol 2009;23:753-64.

41. Scheepens JF, Stöcklin J, Pluess AR. Unifying selection acts on competitive ability and relative growth rate in Scabiosa columbaria. Basic Appl Ecol 2010;11:612-8.

42. Manning JC, Goldblatt P. Plants of the Greater Cape Floristic Region 1: The Core Cape Flora. Cape Town: Strelitzia 29, South African National Biodiversity Institute; 2012.

43. Dimopoulos P, Raus T, Bergmeier E, Constantinidis T, Iatrou G, Kokkini S, et al. Vascular Plants of Greece: An Annotated Checklist. Berlin: Botanic Gardens and Botanical Museum; 2013.

44. Snijman DA. Plants of the Greater Cape Floristic Region. Vol. 2. The Extra Cape Flora. Pretoria: Strelitzia 30, South African National Biodiversity Institute; 2013.

45. Retief E, Meyer NL. Plants of the Free State Inventory and Identification Guide. Pretoria: Strelitzia 38, National Botanical Institute; 2017.

46. Hyde MA, Wursten BT, Ballings P, Palgrave CM. Flora of Zimbabwe: Species information: Scabiosa columbaria L.; 2019. Available from: https://www.zimbabweflora.co.zw/speciesdata/species.php?species id=156960. [Last accessed on Apr 2019 15].

47. Pluess AR, Stöcklin J. Genetic diversity and fitness in Scabiosa columbaria in the Swiss Jura in relation to population size. Conserv Genet 2004;5:145-56.

48. Guarino C, De Simone L, Santoro S. Ethnobotanical study of the Sannioarea, Campania, Southern Italy. Ethnobot Res Appl 2008;6:255-317.

49. Bijlsma R, Ouborg NJ, Van Treuren R. On genetic erosion and population extinction in plants: A case study in Scabiosa columbaria and Salvia pratensis. In: Loeschcke V, Jain SK, Tomiuk J, editors. Conservation Genetics. Basel: Birkhäuser; 1994. p. 225-71.

50. Angeloni F, Vergeer P, Wagemaker CA, Ouborg NJ. Within and between population variation in inbreeding depression in the locally threatened perennial Scabiosa columbaria. Conserv Genet 2014;15:331-42.

51. Niemelä J, Baur B. Threatened species in a vanishing habitat: Plants and invertebrates in Calcareous grasslands in the Swiss Jura mountains. Biodivers Conserv 1998;7:1407-16.

52. Naanyane O. Scabiosa columbaria L; 2015. Available from: http://www. pza.sanbi.org/scabiosa-columbaria. [Last accessed on 2019 Apr 10].

53. Van Wyk BE, Van Oudtshoorn B, Gericke N. Medicinal plants of South Africa. Pretoria: Briza Publications; 2013.

54. Guillarmod AJ. Flora of Lesotho. Lehre: Cramer; 1971.

55. Guillarmod AJ. A medicine chest from the veld: Basotho materiamedica. Veld Flora 1981;5:113-5

56. Maliehe EB. Medicinal Plants and Herbs of Lesotho. Maseru: Mafeteng Development Project; 1997.

57. Moteetee A, Van Wyk BE. The medical ethnobotany of Lesotho: A review. Bothalia 2011;41:209-28

58. Maroyi A. From traditional usage to pharmacological evidence: Systematic review of Gunneraperpensa L. Evid Based Complement Altern Med 2016;2016:1720123.

59. Maroyi A. Dicoma anomala Sond: A review of its botany, ethnomedicine, phytochemistry and pharmacology. Asian J Pharm Clin 
Res 2018;11:70-7.

60. Schmitz MO. Wild Flowers of Lesotho. Roma: ESSA; 1982.

61. Mhlongo LS, Van Wyk BE. Zulu medicinal ethnobotany: New records from the Amandawe area of KwaZulu-Natal, South Africa. S Afr J Bot 2019;122:266-90.

62. Watt JM, Breyer-Brandwijk MG. The Medicinal and Poisonous Plants of Southern and Eastern Africa. Edinburgh: E ande S Livingstone; 1962.

63. Maroyi A. Phytochemical and ethnopharmacological review of Heteropyxis natalensis. Asian J Pharm Clin Res 2019;12:8-15.

64. Guarrera PM, Savo V. Wild food plants used in traditional vegetable mixtures in Italy. J Ethnopharmacol 2016;185:202-34

65. Mugomeri E, Chatanga P, Raditladi T, Makara M, Tarirai C. Ethnobotanical study and conservation status of local medicinal plants: Towards a repository and monograph of herbal medicines in Lesotho. Afr J Tradit Complement Altern Med 2016;13:143-56.

66. Watt JM, Brandwijk MG. Suto (Basuto) medicines. Bantu Stud 1927:3:73-100.

67. Hutchings A, Scott AH, Lewis G, Cunningham AB. Zulu Medicinal Plants: An Inventory. Pietermaritzburg: University of Natal Press; 1996.

68. Long C. Swaziland's Flora: siSwati Names and Uses. Mbambane, Swaziland: Swaziland National Trust Commission; 2005. Available from: http://www.sntc.org.sz/index.asp. [Last accessed on 2019 Apr 14].

69. Van Wyk BE, Gericke N. Peoples' Plants: A Guide to Useful Plants of Southern Africa. Pretoria: Briza Publications; 2007.

70. Karaköse M, Karaköse GC. Medicinal and aromatic plants of Esenli (Giresun) forest planning unit. Int J Second Metab 2017;4:285-305.

71. Cocks ML, Dold AP. Cultural significance of biodiversity: The role of medicinal plants in urban African cultural practices in the Eastern Cape, South Africa. J Ethnobiol 2006;26:60-81.

72. Pooley E. A Field Guide to Wild Flowers of KwaZulu-Natal and the Eastern Regions. Durban: Natal Flora Publication Trust; 1998

73. Horn MM, Drewes SE, Brown NJ, Munro OQ, Meyer JJ, Mathekga AD, et al. Transformation of naturally-occurring 1,9-trans-9,5-cis sweroside to all trans sweroside during acetylation of sweroside aglycone. Phytochemistry 2001;57:51-6.

74. Steenkamp V. Traditional herbal remedies used by South African women for gynaecological complaints. J Ethnopharmacol 2003;86:97-108.

75. Abdillahi HS, Van Staden J. Application of medicinal plants in maternal healthcare and infertility: A South African perspective. Planta Med 2013;79:591-9.

76. Kose LS, Moteetee A, Van Vuuren S. Ethnobotanical survey of medicinal plants used in the Maseru district of Lesotho. J Ethnopharmacol 2015; 170:184-200.

77. Seleteng-Kose L. Evaluation of Commonly used Medicinal Plants of Maseru District in Lesotho for their Ethnobotanical Uses, Antimicrobial Properties and Phytochemical Compositions. PhD Thesis. Johannesburg: University of Johannesburg; 2017.
78. Gerstner J. A preliminary checklist of Zulu names of plants with short notes. Bantu Stud 1939;13:307-26.

79. Zukulu S, Dold T, Abbott T, Raimondo D. Medicinal and charm plants of Pondoland. Pretoria: South African National Biodiversity Institute; 2012 .

80. Thornton-Barnett SR. Ancestral Pharmacopoeias: A Paleoethnobotanical Assessment of Plant use in the Western Free State, South Africa. MSc Dissertation. Texas: Texas State University; 2013.

81. Seleteng-Kose L, Moteetee A, Van Vuuren S. Medicinal plants used for the treatment of sexually transmitted infections in the Maseru district, Lesotho: Antimicrobial validation, phytochemical and cytotoxicity studies. S Afr J Bot 2019;122:457-66.

82. Rigat M, Bonet MA, Garcia S, Garnatje T, Vallès J. Studies on pharmaceutical ethnobotany in the high river ter valley (Pyrenees, Catalonia, Iberian Peninsula). J Ethnopharmacol 2007;113:267-77.

83. Rigat M, Vallès J, Iglésias J, Garnatje T. Traditional and alternative natural therapeutic products used in the treatment of respiratory tract infectious diseases in the eastern Catalan Pyrenees (Iberian peninsula). J Ethnopharmacol 2013;148:411-22.

84. Pinto DC, Rahmouni N, Beghidja N, Silva AMS. Scabiosa genus: A rich source of bioactive metabolites. Medicines (Basel) 2018;5:e110.

85. Agelet A, Vallès J. Studies on pharmaceutical ethnobotany in the region of Pallars (Pyrenees, Catalonia, Iberian Peninsula). Part I. General results and new or very rare medicinal plants. J Ethnopharmacol 2001;77:57-70

86. Moteetee A, Kose LS. Medicinal plants used in Lesotho for treatment of reproductive and post reproductive problems. J Ethnopharmacol 2016;194:827-49.

87. Hutchings A. Zulu Medicinal Plants. Pietermaritzburg: University of Natal Press; 1996.

88. van Vuuren SF, Naidoo D. An antimicrobial investigation of plants used traditionally in Southern Africa to treat sexually transmitted infections. J Ethnopharmacol 2010;130:552-8.

89. Grierson DS, Afolayan AJ. An ethnobotanical study of plants used for the treatment of wounds in the Eastern Cape, South Africa. J Ethnopharmacol 1999;67:327-32

90. Mabona U. Antimicrobial Activity of Southern African Medicinal Plants with Dermatological Relevance. MSc Dissertation. Johannesburg: University of the Witwatersrand; 2013.

91. Mabona U, Van Vuuren SF. Southern African medicinal plants used to treat skin diseases. S Afr J Bot 2013;87:175-93.

92. Twilley D, Lall N. African plants with dermatological and ocular relevance. In: Kuete V, editor. Toxicological Survey of African Medicinal Plants. London: Elsevier; 2014. p. 493-512.

93. Vinnitska RB. Studies of phthalates pigeon scabious (Scabiosa columbaria L.). Farm Zh 2018;1:59-63. 